\section{Antibody Responses of the Domestic Fowl to Two Soluble Bacterial Antigens}

For some years now virologists have recognized the value of the domestic fowl as a means of obtaining high-titred antisera to viral and rickettsial antigens. Bacteriologists and immunologists have almost invariably preforred the rabbit, consequently little information is available about the responses of fowls to soluble bacterial antigens. While investigating the immunological tolerance of diphtheria alumprecipitated toxoid in the domestic fow ${ }^{1}$ I had the opportunity of collecting a limited amount of information about the primary and secondary antibody responses of White Leghorn fowls to both tetanus alumprecipitated toxoid (Wellcome series $W 6874 A$ ) and diphtheria alum-precipitated toxoid (Wellcome series $B A 6403 A$ ) ; though only one dosage of each antigen was usod, the rosults may bo of value to other workers.

Twenty birds between the ages of 10 and 14 months were used in the oxperiment. One group of ten was given a primary stimulus of $1.0 \mathrm{ml}$, diphtheria alumprecipitated toxoid $\left(20 L_{f}\right)$ intramuscularly; the other received $1.0 \mathrm{ml}$. tetanus alum-precipitated toxoid $\left(50 L_{f}\right)$ by a similar route. A sample of blood was taken from each bird immediately before primary challenge and then at 3- or 4-day intorvals for 31 days. A second dose $(1.0 \mathrm{ml}$.) of the respective antigens was given intramuscularly 34 days after the last bleeding (that is, 65 days after primary challenge). The fowls were bled immediately before this injection and then at intervals of 2 or 3 days for the next 15 days.

The serum was separated from these blood samples by centrifugation and the appropriate samples tested for their diphtheria antitoxin content (Romer and Samos ${ }^{2}$, as modified by Glenny and LlewellynJones ${ }^{3}$ ), or their tetanus antitoxin content4.

Fig. 1 shows the average primary and secondary antibody response of ten fowls to diphtheria alumprecipitated toxoid. Antibody to this antigen was

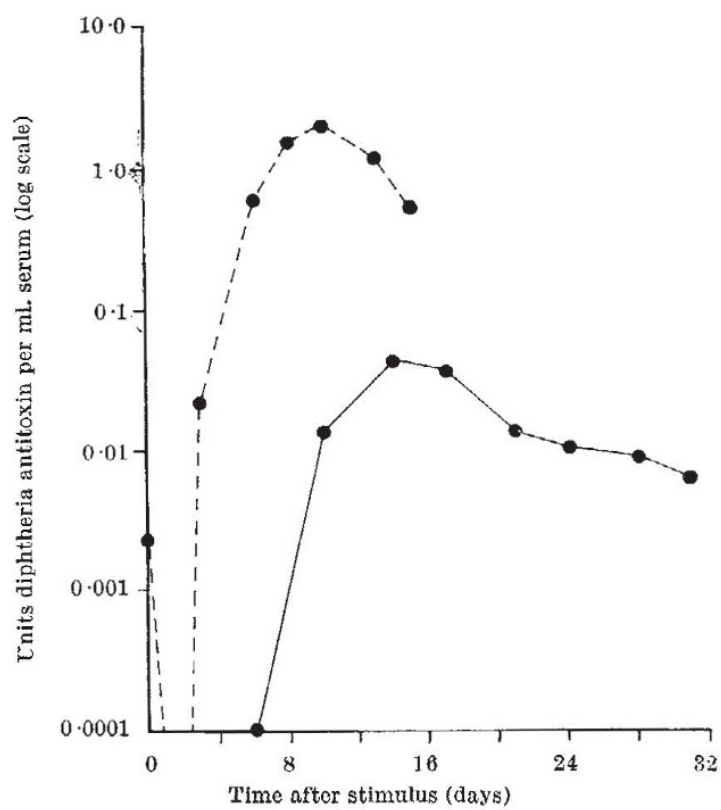

l'ig. 1. A verage antiboly responses of 10 birds to the primary ) and secondary (e--- $)$ antigenic stimulus with
diphtheria alum-precipitated toxoid

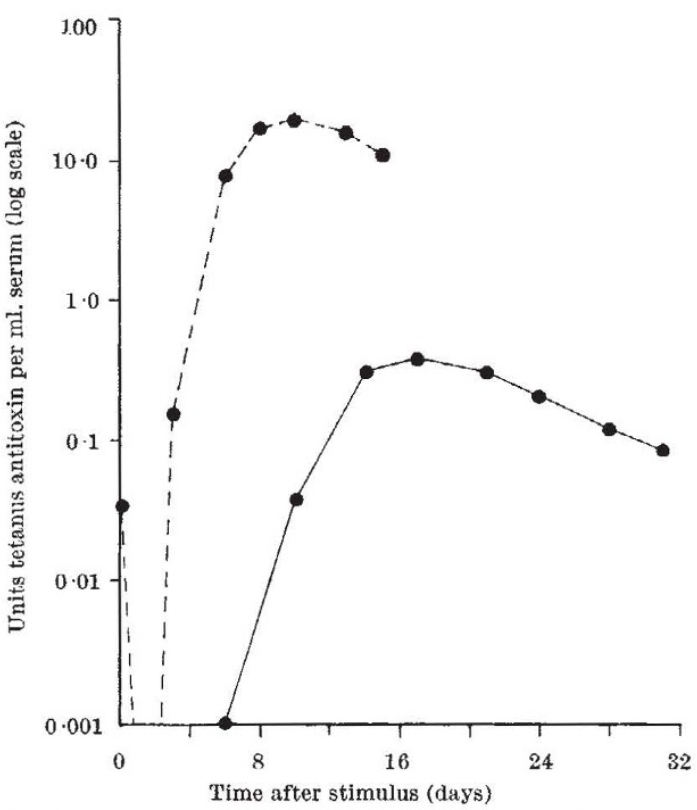

Fig. 2. Avcrage antibody responses of 10 birds to the primary

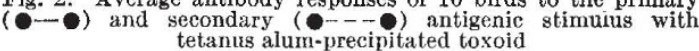

first detected 10 days after primary stimulation, reached a maximum in most cases on the fourteenth day and then gradually declined. After secondary stimulation, antibody was always detectable after 3 days and reached maximum concentration between the eighth and thirtoonth day, tho tenth day after injection being the most usual.

Fig. 2 shows the primary and secondary antibody responses to tetanus alum-precipitated toxoid. These responses are similar in form to those with diphtheria alum-precipitated toxoid as the antigen, except that the maximum response to primary ehallenge with tetanus alum-precipitated toxoid appears to be delayed for about three days and is therefore not usually reached until the seventeenth day. This finding was general among the group.

The individual maximum antibody concentrations reached were $0 \cdot 1$ I.U. diphtheria antitoxin and $3 \cdot 0$ I.U. tetanus antitoxin per ml. of serum during the primary response, and during the secondary response 5.0 I.U. diphtheria antitoxin and 65 x.v. tetanus antitoxin. There was, of course, considerable individual variation in the amounts of antibody produced, but, as can be seen from the figures, the antibody responses in these birds compare favourably with those obtainable in the rabbit under similar conditions.

A number of fowls were also injected with both antigens simultaneously ${ }^{1}$, one antigen being injected into each leg. Results similar to those described above were obtained and there was no evidence of any interference between the two antigens.

Department of Bacteriology,

G. Gowtand

School of Medicine,

Leeds, 2.

March 17.

${ }^{1}$ Gowland, G., and Oakley, C. L., J. I'ath. Bact. (in the press).

${ }^{2}$ Romer, P. I., and Sames, T., Z. ImmunForseh., 3, 334 (1909).

${ }^{3}$ Gleniy, A. T., and Tlewellyn-Jones, Mona, J. Path. Bact., 34, 143 (1931).

- Glenny, A. T., and Stevens, Muriel, F., J. Roy. Army Med. Corps, 70, $308(1938)$ 